\title{
STUDI LITERATUR KEEFEKTIFAN KELAS VIRTUAL DALAM PEMBELAJARAN FISIKA DI MASA PANDEMI
}

\author{
F.F.S. Lestari ${ }^{1 *}$, M. Hamdan ${ }^{1}$, dan Susilawati ${ }^{1}$ \\ ${ }^{1}$ Program Studi Pendidikan Fisika, Fakultas Pendidikan Islam dan Keguruan \\ Universitas Garut, Indonesia \\ Jl. Raya Samarang No. 52A, Garut. \\ E-mail: fuzifitri8@gmail.com
}

\begin{abstract}
Abstrak
Dengan adanya wabah penyakit COVID-19 banyak negara di berbagai dunia memutuskan untuk menutup sekolah, perguruan tinggi maupun universitas. Kondisi tersebut memaksa seluruh kegiatan pembelajaran dilaksanakan secara online atau kelas virtual melalui berbagai media pembelajaran salah satunya Google Classroom. Google Classroom yaitu aplikasi pembelajaran campuran untuk ruang lingkup pendidikan yang dapat mempermudah dosen dalam membuat, membagikan, dan mengelompokkan tugas-tugas yang diberikan. Tujuan diadakannya penelitian ini yaitu untuk mendeskripsikan hasil studi pustaka keefektifan virtual class dalam pembelajaran fisika menggunakan Google Classroom dimasa Covid-19. Metode yang digunakan dalam penelitian ini yaitu menggunakan pendekatan deskriptif kualitatif dengan jenis penelitian yang digunakan adalah kepustakaan (library research). Hasil menunjukkan bahwa penggunaan Google Classroom dalam Pembelajaran Fisika Dimasa COVID-19 dapat dikatakan sudah efektif, apalagi disertai dengan video materi pembelajaran yang menarik sehingga dapat menimbulkan motivasi serta ketertarikan mahasiswa dalam proses pembelajaran, dan mampu meningkatkan hasil pembelajaran mahasiswa.
\end{abstract}

Kata kunci: fisika; google classroom; keefektifan kelas

\section{Pendahuluan}

Pandemi COVID-19 merupakan musibah yang memilukan bagi seluruh penduduk bumi. Seluruh segmen kehidupan manusia di muka bumi terganggu seperti ekonomi, politik dan tanpa terkecuali dunia pendidikan. Dengan adanya wabah penyakit COVID-19 yang sangat mendadak banyak negara di berbagai dunia memutuskan untuk menutup sekolah, perguruan tinggi maupun universitas. kondisi tersebut memaksa kegiatan pembelajaran dilakukan secara virtual class, termasuk di Indonesia.

Virtual Class (kelas maya) adalah lingkungan belajar yang diadakan tanpa tatap muka secara langsung antara dosen dengan mahasiswa di mana pendidik menyediakan bahan ajar dalam konten digital yang bisa diakses, disimpan, dan dibagikan melalui internet yang bisa diakses kapan saja dan di mana saja. Kelas maya menyediakan fasilitas yang digunakan tenaga pendidik untuk mengunggah bahan ajar sehingga bisa diunduh langsung oleh peserta didik yang bergabung dalam kelas tersebut.

Menurut Kristiawan dalam Wati dan Kamila (2019), seorang dosen atau pendidik harus bisa memanfaatkan teknologi untuk meningkatkan kualitas proses belajar mengajar pada setiap satuan pendidikan. Menurut Atsani (2020), pendidik dituntut kreatif dalam penyampaian materi melalui media pembelajaran virtual. Di 
mana masa pandemi Covid-19 dapat dikatakan sebagai peluang bagi dunia pendidikan baik dalam pemanfaatan teknologi sejalan dengan tuntutan industri 4.0. Oleh sebab itu, dalam proses pembelajaran tenaga pendidik harus mampu menguasai berbagai media pembelajaran karena kondisi pendidikan yang selalu berubah-ubah. Terlebih lagi pada kondisi pandemi COVID-19 ini yang menuntut berbagai sektor untuk menyesuaikan keadaan. Berdasarkan pendapat tersebut, dapat dikatakan bahwa seorang pendidik harus memanfaatkan kreativitasnya untuk menginovasi media pembelajaran yang akan digunakan untuk menunjang proses penyampaian kegiatan belajar mengajar.

Google Classroom yaitu aplikasi pembelajaran campuran untuk ruang lingkup pendidikan yang dapat mempermudah tenaga pendidik dalam membuat, membagikan, dan mengelompokkan tugas-tugas yang diberikan. Google mengklaim bahwa salah satu produknya, yaitu Google Classroom, merupakan piranti produktivitas yang gratis meliputi email, dokumen, dan penyimpanan. Dengan Google Classroom ini memudahkan dosen dan mahasiswa untuk saling terhubung di dalam maupun di luar kelas. Adapun beberapa kelebihan yang dapat dirasakan oleh mahasiswa dan dosen yaitu memudahkan dosen dalam membuat dan mengelola kelas, tugas, nilai serta memberikan masukan secara langsung, mahasiswa dapat mengakses maupun berbagi materi dan tugas kelas, berinteraksi dalam kelas atau email, dapat memudahkan mahasiswa dalam mengirim tugas, tidak memakan cukup banyak ruang di handphone karena terhubung dengan google drive, dan lain sebagainya.

Fisika merupakan cabang ilmu pengetahuan alam yang pada dasarnya bertujuan untuk mempelajari dan memberi pemahaman kuantitatif terhadap berbagai proses alam dan sifat zat serta penerapannya. Pembelajaran Fisika banyak sekali kaitannya dengan rumus-rumus, sehingga dalam proses pembelajarannya guru harus menjelaskan rumus-rumus serta memberikan contoh-contoh penerapannya dalam kehidupan sehari-hari. Oleh karena itu dengan adanya Google Classroom dapat memudahkan tenaga pendidik dalam memberikan penjelasan baik berupa video pembelajaran, file atau dokumen pada setiap materi pembelajaran. Berdasarkan uraian di atas maka penulis tertarik untuk melakukan penelitian dengan judul: "Studi Literatur Keefektifan Virtual Class Dalam Pembelajaran Fisika Menggunakan Google Classroom Dimasa Covid-19”. Tujuan dari penelitian ini untuk mengetahui seberapa efektif penggunaan Google Classroom dalam pembelajaran fisika dimasa Covid-19.

\section{$2 \quad$ Metodologi}

Metode yang digunakan dalam penelitian ini yaitu menggunakan pendekatan deskriptif kualitatif, dan jenis penelitian yang digunakan adalah kepustakaan (library research), yaitu mengumpulkan data atau karya tulis ilmiah yang berkaitan dengan obyek penelitian atau pengumpulan data yang bersifat kepustakaan. Studi pustaka adalah teknik pengumpulan data dengan mengadakan studi penelaahan terhadap buku-buku, literaturliteratur, catatan-catatan, dan laporan-laporan yang relevan dengan masalah yang ada hubungannya dengan masalah yang dipecahkan (Nazir, 1988;111). Menurut Zed (2003), pada penelitian studi literatur paling tidak harus ada empat karakteristik, diantaranya: 1) penulis yang berhadapan langsung dengan naskah, 2) data pustaka yang siap digunakan, 3) data pustaka merupakan sumber sekunder, dan 4) kondisi data pustaka tidak dibatasi ruang dan waktu. Berdasarkan hal tersebut, sumber data yang digunakan adalah sumber data sekunder. Menurut Sugiono (2008), data sekunder merupakan sumber data yang tidak memberi data secara langsung. Sumber data sekunder yang digunakan adalah catatan atau dokumen seperti buku-buku, literatur serta bacaan dari media, situs, website dan seterusnya yang sifatnya mendukung keperluan penelitian. Sehingga sumber tersebut dapat dianalisis dan disajikan dalam hasil pembahasan agar dapat dibuat sebuah kesimpulan.

\section{$3 \quad$ Hasil dan Pembahasan}

Di era pandemi COVID-19 ini, semua proses pembelajaran dilaksanakan menggunakan kelas virtual, sehingga pendidik dituntut kreatif dalam penyampaian materi melalui media pembelajaran daring. Terdapat 
beberapa media pembelajaran yang dapat digunakan dalam proses pembelajaran virtual class, salah satunya Google Classroom. Google Classroom merupakan aplikasi khusus yang digunakan untuk pembelajaran online atau jarak jauh sehingga memudahkan pengajar untuk membuat, mengelompokkan dan membagikan tugas. Selain itu pengajar dan peserta didik dapat setiap saat melakukan kegiatan pembelajaran melalui virtual class dengan menggunakan Google Classroom sehingga peserta didik juga dapat belajar, menyimak, membaca serta mengirim tugas di mana pun dan kapan pun. Berikut beberapa kelebihan yang dapat dirasakan oleh dosen dan mahasiswa yaitu memudahkan dosen dalam membuat dan mengelola kelas, tugas, nilai serta memberikan masukan secara langsung, peserta didik dapat mengakses maupun berbagi materi dan tugas kelas, berinteraksi dalam kelas atau email, dapat memudahkan mahasiswa dalam mengirim tugas, tidak memakan cukup banyak ruang di handphone karena terhubung dengan google drive.

Selain hal tersebut, Google Classroom merupakan media pembelajaran sederhana yang dapat memudahkan mahasiswa dan juga dosen dalam menggunakannya. Hal ini sejalan dengan pendapat Hakim (2016) bahwa penggunaan Google Classroom memudahkan pendidik dalam mengelola pembelajaran dan menyampaikan informasi secara tepat dan akurat kepada mahasiswa. Google Classroom selain dapat diakses melalui aplikasi juga dapat dibuka di situs Google Classroom yaitu https://classroom.google.com.

Adapun keberhasilan dalam suatu pembelajaran ditentukan oleh beberapa aspek diantaranya adalah pendidik/dosen mampu merancang dan merencanakan strategi, media, metode serta bahan ajar guna tercapainya suatu pembelajaran yang interaktif dan komunikatif. Keefektifan pembelajaran fisika menggunakan Google Classroom dapat dilihat berdasarkan tingkat kesalahan yang dibuat mahasiswa saat menyelesaikan tugas-tugas yang diberikan. Selain itu, hal lain yang menjadi acuan keefektifan pembelajaran adalah pada saat dosen memotivasi mahasiswa untuk mempelajari materi yang telah diunggah ke dalam Google Classroom.

Berdasarkan hasil penelitian Andira dan Yoga Budi Bhakti (2020) menggambarkan bahwa pada kondisi COVID-19 ini, penggunaan Google Classroom dalam pembelajaran virtual class dapat dikatakan sudah efektif, karena peserta didik dapat menerima Google Classroom dengan mudah dari segi penggunaan, tampilan serta memperoleh akses informasi, materi, dan tugas yang lebih efisien. Namun, dalam pembelajaran fisika penggunaan Google Classroom belum efektif karena pada hakikatnya peserta didik masih membutuhkan dosen yang secara langsung terlibat dalam proses pembelajaran fisika. Jadi, Google Classroom ini efektif digunakan sebagai virtual class hanya untuk beberapa mata kuliah saja, tetapi tidak untuk mata kuliah fisika. Apabila konsep Google Classroom menyediakan video pembelajaran dan video praktikum, maka akan lebih efektif dalam pembelajaran fisika dimasa pandemi COVID-19.

Berdasarkan hasil penelitian Dewi Juita dan Yusmaridi (2020) berpendapat bahwa penggunaan virtual class (kelas maya) dengan Google Classroom dalam pembelajaran fisika sudah efektif apalagi disertai dengan tutor sebaya karena mampu meningkatkan hasil belajar mahasiswa dalam kategori sedang. Meskipun dalam penggunaan Google Classroom dalam virtual class memiliki kendala yang dirasakan baik oleh pengajar maupun peserta didik salah satunya tidak adanya jaringan di tempat mereka tinggal serta belum sanggup dalam membeli paket data.

Sedangkan menurut Silvia Wulandari dan Nana (2021) berdasarkan hasil penelitiannya, model pembelajaran berbasis video efektif digunakan karena berhasil meningkatkan kemampuan pemecahan masalah mahasiswa pada pemecahan masalah yang diberikan. Dalam kondisi saat ini pemanfaatan video berperan memberikan stimulus awal sehingga menimbulkan motivasi dan ketertarikan mahasiswa dalam kegiatan pembelajaran.

Selanjutnya menurut Yulita (2020) berdasarkan hasil penelitiannya bahwa aktivitas kegiatan belajar mengajar secara daring dalam pembelajaran fisika berjalan kurang efektif. Berikut beberapa faktor penyebab pembelajaran tidak terlaksana dengan baik diantaranya pembelajaran yang kurang terstruktur, jadwal selalu berubah, dan tidak terkoordinasi dengan baik. Hal ini dimungkinkan karena dosen dan mahasiswa belum terbiasa menggunakan model pembelajaran daring, yang mana pembelajaran yang sebelumnya dilakukan secara offline. Dan juga terdapat beberapa kendala terhadap pemahaman mahasiswa terhadap materi yang diajarkan oleh dosen diantaranya adalah pembelajaran yang diberikan lebih dominan teoritis dan kegiatan praktikum belum optimal dilaksanakan, beberapa dari mahasiswa kesulitan dalam mengakses jaringan internet serta tidak semua mahasiswa memiliki perangkat yang dibutuhkan (seperti laptop, komputer, atau lainnya) untuk mengakses pembelajaran online. 


\section{Kesimpulan}

Berdasarkan hasil studi kepustakaan dari beberapa jurnal nasional serta sumber-sumber data atau informasi lainnya yang dianggap relevan dengan penelitian dapat diambil kesimpulan bahwa penggunaan Google Classroom dalam Pembelajaran Fisika Dimasa COVID-19 dapat dikatakan sudah efektif, apalagi disertai dengan video materi pembelajaran yang menarik sehingga dapat menimbulkan motivasi serta ketertarikan mahasiswa dalam proses pembelajaran. Serta mampu meningkatkan kemampuan pemecahan masalah mahasiswa terhadap masalah yang disajikan dan dapat meningkatkan hasil belajar mahasiswa.

\section{Daftar Pustaka}

2, D. P. (2021). Kelas Maya. Retrieved May 15, 2021, from Dosen Pendidikan: https://www.dosenpendidikan.co.id/kelas-maya/

Bhakti, A. P. (2020). Keefektifan Virtual Class dengan Google Classroom dalam Pembelajaran Fisika Dimasa Pandemi Covid-19. JIPFRI 4, no. 1 (Mei, 2020), 4, 27-33. doi:10.30599/jipri.v4i1.669

Dewi Juita, Y. M. (2020). Efektivitas Mobile Learning Dengan Google Classroom Disertai Tutor Sebaya Pada Mata Kuliah Fisika Dasar. Journal of Teaching and Learning Physics 5, 2 (2020), 5, 60-69. Retrieved from http://journal.uinsgd.ac.id/index.php/jtlp/index

Lede, Y. A. (2020). Efektivitas Pelaksanaan Pembelajaran Daring Program Studi Pendidikan IPA dan Pendidikan Fisika STKIP Weetebula. SAINTIFIK 6,no. 2 (July, 2020), 6, 175-182. doi:10.31605/saintifik.v6i2.314

Nilakandi, Z. (2020). Pengertian Google Classroom Beserta Manfaat, Kelebihan dan Kekurangannya. Retrieved April 29, 2021, from Nesaba Media: https://www.nesabamedia.com/pengertian-googleclassroom/

Sabara, S. d. (n.d.). Keefektifan Google Classroom sebagai media pembelajaran. Prosiding Seminar Nasional Lembaga Penelitian Universitas Negeri Makasar, 122-125.

Setiawan, P. (2021). Pengertian dan Cabang Fisika Beserta Manfaatnya. Retrieved May 8, 2021, from Guru Pendidikan: https://www.gurupendidikan.co.id/pengertian-fisika/

Silvia Wulandari, N. (2021). Studi Literatur Penggunaan PBl Berbasis Video Untuk Meningkatkan Kemampuan Pemecahan Masalah. Jurnal Pendidikan Fisika 9, no. 1 (Maret, 2021), 9, 7-17. Retrieved from https://journal.uin-alauddin.ac.id/indexs.php/PendidikanFisika

Widya Mutiara Mukti, Y. B. (2020). Media Pembelajaran Fisika Berbasis Web Menggunakan Google Sites Pada Materi Listrik Statis. FKIP e-PROCEEDING 5, no. 1 (Desember, 2020), 5, 51-59. Retrieved from https://jurnal.unej.ac.id/index.php/fkip-epro/article/view/21703 